\title{
Morphological and cytophysiological changes in selected lines of normal and cancer human cells under the influence of a radio-frequency electromagnetic field
}

\author{
Romuald Górski ${ }^{1, A, D-F}{ }^{\oplus}$, Agnieszka Nowak-Terpiłowska ${ }^{1, A-D \oplus}$, Paweł Śledziński ${ }^{1, C \oplus}$, \\ Mikołaj Baranowski ${ }^{2, D \oplus}$, Stanisław Wosiński3i,A \\ ${ }^{1}$ University of Life Sciences, Poznań, Poland \\ ${ }^{2}$ Adam Mickiewicz University, Poznań, Poland \\ ${ }^{3}$ ADR Technology, Poznań, Poland \\ A - Research concept and design, B - Collection and/or assembly of data, C - Data analysis and interpretation, \\ $D$ - Writing the article, E - Critical revision of the article, F - Final approval of article, \# - Contributed equally \\ Nowak-Terpiłowska A, Górski R, Śledziński P, Baranowski M, Wosiński S. Morphological and cytophysiological changes in selected lines of \\ normal and cancer human cells under the influence of a radio-frequency electromagnetic field. Ann Agric Environ Med. $2021 ; 28(1)$ : 163-171. \\ doi: $10.26444 /$ aaem/118260
}

\section{Abstract}

Introduction. Currently, mobile phones and Wi-Fi are the most commonly used forms of telecommunication. The popularity of mobile telecommunications has made it necessary to investigate the problem more comprehensively and cautiously assess the possible risks, because never before in history has such a substantial proportion of the population been exposed to microwaves at comparably high levels. Some studies indicate that the high frequency electromagnetic radiation emitted by mobile phone and Wi-Fi connections can have a negative effect on human health, and can cause cancer.

Objective. The aim of the study was to investigate the influence of the radiofrquency electromagnetic field (RF-EMF) on the metaboloc activity and morphology of normal human cells (fibroblasts) and cancer cells (prostate cancer cells).

Matherials and method. The cell cultures (human fibroblasts and prostate cancer cells) were exposed to RF-EMF at the frequency of $2.5 \mathrm{GHz}$ for 24,48 and $72 \mathrm{~h}$. To quantify changes in cell viability, the Cell Counting Kit - 8 was used.

Results. It was found that the RF electromagnetic field exposure caused a significant decrease in the viability of fibroblasts, and a significant increase in cancer cells. Morphological analysis did not show significant changes in both cell lines after exposure to RF-EMF.

Conclusion. On the basis of the obtained results, the hypothesis can be formulated that a high frequency electromagnetic field can have harmful effects on human cells.

\section{Key words}

metabolic activity, morphology, fibroblasts, cells of prostate cancer, radio-frequency electromagnetic field

\section{INTRODUCTION}

Mobile phones and Wi-Fi are now an integral part of modern telecommunications. The use of mobile phones is widespread globally with a high prevalence among almost all age groups, which poses a potential concern for public health. The use of mobile phones has increased rapidly in recent years. At the end of 2017, there were worldwaide over 5 billion individual mobile phone subscriptions, equivalent to $66 \%$ of the world's population. By 2020, almost three-quarters of the global population will have a mobile subscription [1]. The popularity of mobile telecommunications has made it necessary to investigate the problem more comprehensively and cautiously assess the possible risks, because never before in history has such a substantial proportion of the population been exposed to microwaves and at comparably high levels. Mobile phones emit electromagnetic energy waves of radio frequencies which can have a carcinogenic effect upon people. In 2011, the International Agency for Research on Cancer

Address for correspondence: Agnieszka Nowak-Terpiłowska, University of Life Sciences, Poznań, Poland

E-mail: nwk.agnieszka@gmail.com

Received: 22.11.2019; accepted: 18.02.2020; first published: 17.03 .2020
(IARC) at WHO evaluated the carcinogenic effect to humans from radiofrquency electromagnetic fields (RF-EMF), and included radiation from mobile phones and from other devices that emit similar non-ionising electromagnetic fields. It was concluded that RF-EMF has a group $2 \mathrm{~B}$ classification, i.e. a 'possible human carcinogen' [2]. The use of mobile phones has increased the risk of brain tumours (glioma, meningioma, acoustic neuroma), since the brain is the targeted organ for radiation exposure during mobile phone calls. The first reports of an increased risk for brain tumours associated with the use of mobile phones was published 18 years ago [3]. In the following years, the impact of mobile telephony on the development of malignant and benign brain tumors has been confirmed [4-7]. Exposure to radiation from mobile phones is generally highest in the part of the brain that is near to the ear, the temporal lobe on the same side of the head to which the phone is generally held. In the conducted research [8] it was found that most - 97-99\% of radiofrquency (RF) energy - is absorbed in the brain hemisphere on the side where the phone is used, generally (50-60\%) in the temporal lobe.

The development of brain tumors under the influence of electromagnetic radiation emitted from mobile phones is 
particularly exacerbated regarding young people. Hardell et al. [9] reported that after even just one or more years of use there is a 5.2 -fold elevated risk of malignant brain tumors in people who begin to use mobile phones before the age of 20 years, whereas for all ages the odds ratio was 1.4. A study showed that children absorb twice the amount of RF from mobile phone use as adults [10]. This is caused by the smaller brain size, a thinner pinna of the ear, thinner skin and thinner skull bone, permitting deeper penetration into the child's brain [11]. Acoustic neuroma (vestibular schwannoma) is a nerve sheath tumour of the vestibulocochlear nerve. This tumour is of particular interest in relation to mobile phones because brain deposition of energy from RF fields from a mobile phone is mainly within a small area of the skull, close to the handset, which includes the vestibular portion of the eighth cranial nerve where acoustic neuromas develop.

Several studies have reported relationships between the use of mobile phones and parotid gland tumours [12] and non-Hodgkin's lymphoma [13, 14] and breast cancer [5]. The exposure to microwaves in the radiofrequency fields (RF) during mobile phone calls may also be a risk factor for testicular cancer, especially if the phone is located in a pocket close to the testis [15].

The ancer cell development is due to the DNA damage cause by the action of the high frequency electromagnetic field. The mechanism of DNA changes under the influence of RF-EMF electromagnetic field have not been fully investigated. The energy level associated with RF-EMF exposure is too low to cause direct DNA strand breaks and DNA crosslinks. However, DNA damage can be caused by cellular biochemical activities, such as free radicals. Several studies indicate that RF-EMFs increase free radical activity in cells $[16,17]$. Liu et al. [18] showed that RF-EMF exposure induced the formation of oxidative base damage in a mouse spermatocyte-derived cell line. This was mediated by reactive oxygen species (ROS) production.

The high frequency electromagnetic field not only effects the development of cancer cells but also human fertility. This is indicated by the results of studies conducted on humans and animals. Kilgalton and Simmons [19] who reported negative effects from prolonged use of cell phones upon human sperm motility characteristics. Men who carried mobile phones in their hip pocket or on their belt had lower sperm motility those who did not carry a mobile phone, or who carried it elsewhere on the body. Erogul et al. [20] also showed that RF-EMF emitted by cellular phones influences human sperm motility. Semen exposure to $900 \mathrm{MHz}$ RF-EMF emitted by an activated cellular phone, caused a decrease in the rapid progressive and slow progressive sperm movement. It also caused an increase in the no-motility category of sperm movement. Davoudi et al. [21] observed a reduction in the proportion of rapid progressive sperm from $32.3 \%$ to $26.1 \%$ after one month of 6 hours daily mobile phone use. The high frequency electromagnetic field not only affects the motility of human sperm cells, but also their morphology and other fertility parameters. Gutschi et al. [22] studied human blood and sperm obtained from 2,110 patients attending clinics from 1993 - 2007. In the patients who used mobile phones, $68.0 \%$ of the spermatozoa featured a pathological morphology, compared to only $58.1 \%$ in the men who did not use mobile phones.

At the same time, patients with cell phone usage showed significantly higher testosterone and lower luteinising hormone (LH) levels than those who did not use mobile phones. Also, a study carried out by Wdowiak et al. [23] on a male population using mobile phones (GSM equipment) for a period of 1-2 years, showed an increase in the percentage of sperm cells of abnormal morphology. It was also confirmed that a decrease in the percentage of sperm cells in vital progressing motility in the semen is correlated with the frequency of mobile phone use. Falzone et al. [24] exposed highly motile human spermatozoa to $900 \mathrm{MHz}$ for an hour $(\mathrm{SAR}=2.0 \mathrm{~W} / \mathrm{kg})$. They obtained a significant reduction in sperm head are, and a significant decrease in sperm binding to the hemizona in exposed samples. De Iuliis et al. [25] used human spermatozoa for exposure to electromagnetic radiation at $1.8 \mathrm{GHz}$ with specific absorption rates varying from $0.4-2.75 \mathrm{~W} / \mathrm{kg}$. These authors showed that motility and vitality were significantly reduced after RF-EMF exposure, compared to the control. Similar results were obtained by Avendano et al. [26] who investigated the effect of laptop computers connected to internet through Wi-Fi on human sperm motility. Normozoospermic samples of sperm exposed ex vivo for a 4 hour connection duration. A significant decrease in progressive sperm motility and an increase in sperm DNA fragmentation were found.

The studies conducted on animals also have shown the effect of RF-EMF on fertility. Yan et al. [27] studied the effects of cellular phone emissions on sperm cells in rats. Rats were exposed to two 3-hr periods of daily cellular phone emissions for 18 weeks. The authors showed that the rats exposed exhibited a significantly higher incidence of sperm cell death than the control. In addition, abnormal clumping of sperm cells was present in rats exposed to cellular phone emissions. Otitoloju et al. [28] exposed male mice to radiofrequency radiation at a mobile phone (GSM) base station. The authors found that the electromagnetic field caused morphological changes in the sperm. The major abnormalities observed were knobbed hook, pin head and banana-shaped sperm head. The radiofrequency field can effect not only the testicular function, but also their structure. Salama et al. [29] exposed adult rabbits to a pulsed radiofrequency (of 800 Mhz) emitted by a mobile phone ( $8 \mathrm{hr}$ daily for a period of 12 weeks). The authors showed a drop in sperm concentration and a significant decrease in the diameter of seminiferous tubules after exposure. Also, Dasdag et al. [30], in studies conducted on rats, reported the decrease in seminiferous tubule diameter after exposure 890-915 MHz GSM with $0.141 \mathrm{~W} / \mathrm{kg}$ whole body SAR. In other studies, Aitken et al. [31] found significant damage to the mitochondrial and nuclear genome in the epididymal spermatozoa of mice after exposure to RF $900 \mathrm{MHz}$ EMF for 12 hours a day for 7 days.

In animal studies, it was found that the RF-EMF electromagnetic field not only effects the reproduction of males, but also of females. Gul et al. [32] investigated the toxicity of microwaves emitted by cellular phones on ovaries in pregnant rats. The study revealed that in the exposed female group, the number of follicles was lower than that in the control. In other studies, also carried out on rats, Nakamura et al. [33] found that exposure to a $2.45 \mathrm{GHz}$ continuous wave at $2 \mathrm{~mW} / \mathrm{cm}^{2}$ power density for $90 \mathrm{~min}$, decreased uteroplacental blood flow, increased progesterone and PGF2 in pregnant females.

Electromagnetic waves can not only cause fertility problems but can also cause other dysfunctions of the human body. There is evidence for short-term effects of RF-EMF 
exposure on cognition, memory and learning, behaviour, reaction time, attention and concentration, as well as altered brainwave activity (altered EEG) [34-36]. The relationship of RF-EMF to the human body with the occurrence of neurological effects and neurodegenerative diseases, immune system deregulation, allergic and inflammatory responses, miscarriage, and some cardiovascular effect, have been reported [5]. Insomnia (sleep disruption) is reported in studies of people living in very low-intensity RF environments with Wi-Fi and cell tower-level exposures [37-39].

\section{OBJECTIVE}

The aim of the study was to investigate the influence of radiofrequency electromagnetic field (RF-EMF) on the metabolic activity and morphology of normal humal cells (fibroblasts) and cancer cells (prostate cancer cells).

\section{MATERIALS AND METHOD}

Cell cultivation. Cell cultures of the PC-3 prostate cancer cell line (ATCC ${ }^{\oplus}$ CRL-1435 $5^{\text {Tx }}$ ) and human fibroblasts (own sources) were cultivated. Both cell lines belong to the adherent type and require the same culture conditions. The base medium was Dulbecco's Modified Eagle's Medium (DMEM). To complete the medium, the following ingredients were added: foetal bovine serum to a final concentration of $10 \%$, Nutritient mixture F-12 to a final concentration of $40 \%$, and a mixture of antibiotics (penicillin, streptomycin, amphotericin) to a final concentration of $1 \%$.

The cells were cultured in $25 \mathrm{~cm}^{2}$ culture vessels at $37^{\circ} \mathrm{C}$ at $5 \% \mathrm{CO}_{2}$ concentration. For passage, the cells were washed with Hank's Balanced Salt Solution to remove residual FBS containing the trypsin inhibitor. The cells were then briefly washed with a $0.25 \%$ trypsin solution in a $0.53 \mathrm{mM}$ EDTA solution $(750 \mu \mathrm{l})$.

After 10 minutes of cell incubation with trypsin at $37^{\circ} \mathrm{C}$ in a $5 \% \mathrm{CO}_{2}$ atmosphere, the degree of detachment of the cells from the vascular surface was evaluated using an inverted microscope. To prevent clumping, the cells were mixed by impact or shaking. After the detachment of the cells from the medium, they were filled with $8 \mathrm{ml}$ of a complete culture medium and poured into 2 new vessels. Changes of the culture medium occurred, on average, every 2-3 days until the cells reached $80 \%$ confluence.

Cytotoxicity test Cell Counting Kit - 8. In order to analyze the effect of the electromagnetic field on cells under the conditions of the complete culture medium (10\% FBS), the experiment was conducted as follows: Cells were propagated in culture flasks containing $4 \mathrm{ml}$ of standard culture medium (DMEM, F-12, antibiotic, FBS) to 80\% confluency. After reaching the desired level of confluence, the cells were transferred to the wells of a 96 -well plate $(5000$ cells/100 $\mu \mathrm{l})$ and incubated for 24 hours.

Cells were incubated under the conditions described above in 2 variants. Test samples were exposed to RF electromagnetic field, at $2.4 \mathrm{GHz}$. The control cell lines were cultivated in conditions free from the influence of RFEMF. In the cancer cell experiment, both test and control samples were prostate cancer cells. In the human fibroblast cell experiment, both test and control samples were human fibroblast cells. Incubation was carried out for 72 hours. Cell viability measurements were made after 24,48 and $72 \mathrm{~h}$ of incubation.

To quantify changes in cell viability, the Cell Counting Kit -8 (Sigma-Aldrich) was used. The test consists in using the reaction of reducing the tetrazolium salt (WST-8) for the coloured formazan. The amount of formazan obtained was proportional to the number of metabolically active (living) cells in the population. After the specified cultivation time $(24,48,72 \mathrm{~h}), 10 \mu \mathrm{l}$ of CCK- 8 reagent was added to selected wells of the 96 -well plate. The plate was incubated for $1 \mathrm{~h}$ at $37^{\circ} \mathrm{C}$. Absorbance readings were made at $450 \mathrm{~nm}$ in the ELx808 plate reader (BioTek).

Analysis of changes in cell morphology. Analysis of changes in cell morphology under the influence of RF-EMF was carried out using the Axiovert 200 inverted light microscope. Images of cells exposed to electromagnetic field and control cells were performed after 24,48 and $72 \mathrm{~h}$, respectively.

Experimental setup (an electromagnetic field generator). The experimental setup was constructed on the base of 2 IoT optimized FERMIO-EM mi-computers utilizing the Intel Quark processor. The Bluetooth output/input antenna was connected to an external inverted $\mathrm{F}$ antenna (IFA), which was constructed on a microwave substrate DK 6 from the Rogers company. The devices fulfilled the low energy consumption standard for Bluetooth 4.0. The RF output power of the transmitter was $>7.5 \mathrm{dBm}$, which gave less than $6 \mathrm{~mW}$ of the radiated power when the carrier frequency was introduced to the antenna. The complete device power consumption is only $2.5 \mathrm{~W}$. With the use of a suitable operational system and high-level software, this provided the opportunity to build an independent and powerful measurement system for various types of experiments.

The antenna used in the described experiment was designed on a Rogers laminate because it has a very stable dielectric constant with temperature. The dissipated energy from the antenna remains constant even when the temperature changes. The Rogers3006 substrate exhibits a low dissipation in energy. The laminate is characterized by a dielectric constant of 6.15 . The IFA antenna topology was chosen because of its better radiation effectivity when compared to MIFA; however, the former occupies a larger area.

For the real experiment, a wireless data transfer using a quasi-continuous mode and with an approximate speed of $1 \mathrm{MB} / \mathrm{s}$ over Bluetooth, between the FERMIO-EM devices computers was chosen. The block diagram of the single device is shown in Figure 1. The external antenna was connected to port A via a coaxial transmission line. The impedance of the antenna was matched to $50 \mathrm{Ohms}$. For configuration purposes, each mini-computer was connected to the external router via Ethernet.

The 3D antenna model (Fig. 2) was designed using a two-layer PCB, for simulation purposes. The copper layer thickness was set to $35 \mathrm{um}$ for both top and bottom sides. The ground plane was assigned to the bottom side. Vias were used to connect the top and bottom layers. The completed model was exported as a STL file and was then imported to the CST software. The IFA antenna of the electromagnetic waves source was assembled to a plexiglass holder. Between the antenna and the TC plate, which contained the cells, a sheet 


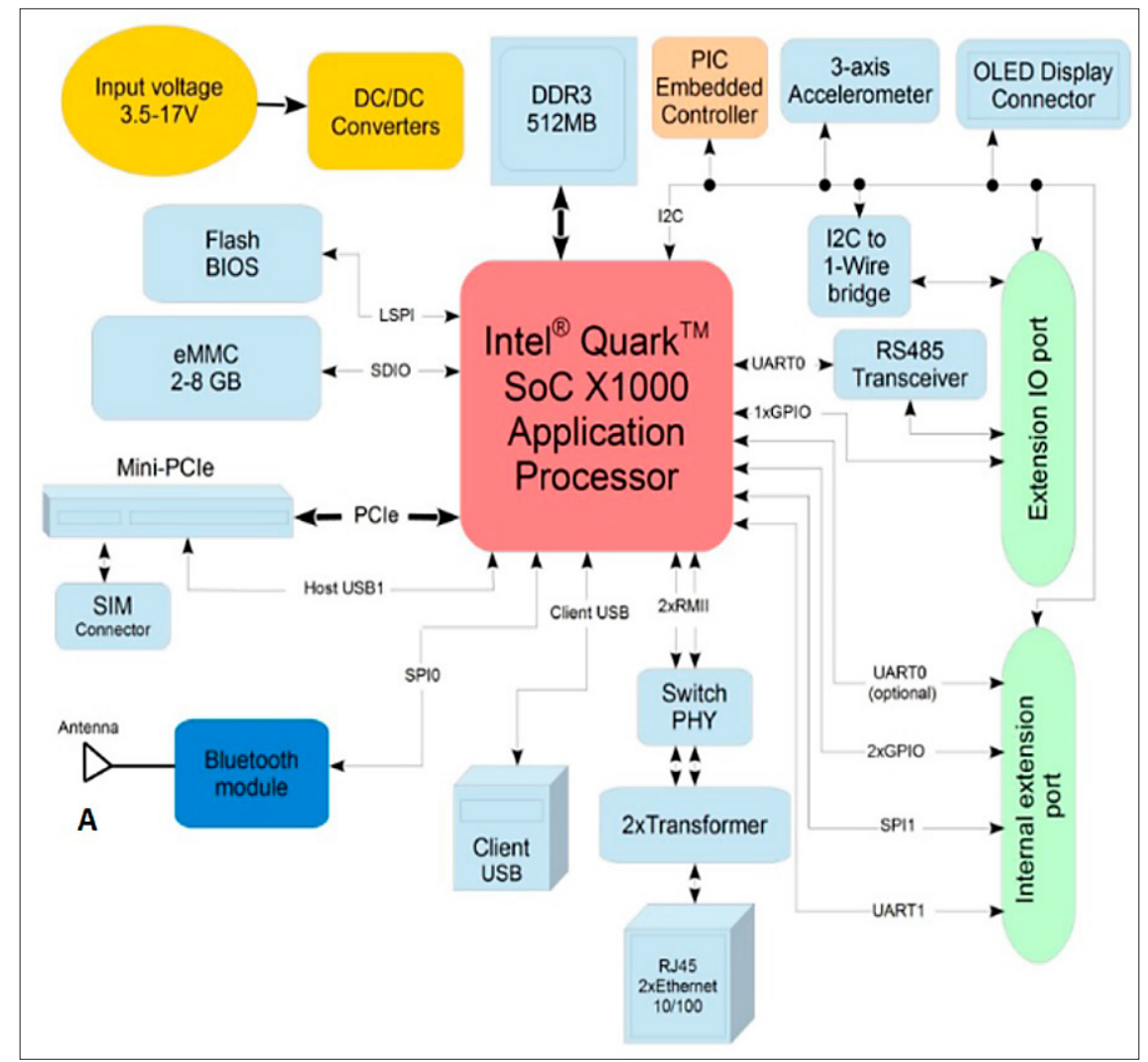

Figure 1. Block schema of the FERMIO-EM IoT designed mini-computer [59]

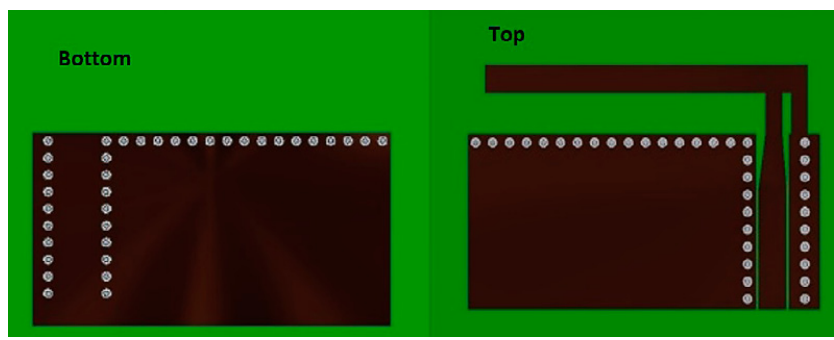

Figure 2.3D model of designed IFA antenna optimized to Bluetooth communication standard. Left - bottom layer; Right - top layer

of plexiglass of $3 \mathrm{~mm}$ height was placed. The 3D model of the experimental setup is shown in Figure 3. Two identical setups were used. The distance between the antennas was around $20 \mathrm{~cm}$. It was ensured that no other $\mathrm{RF}$ radiation was present in the laboratory during the cell irradiation experiment. The numerical simulation of the magnetic and electric fields was performed using the CST software. Each 3D geometry model

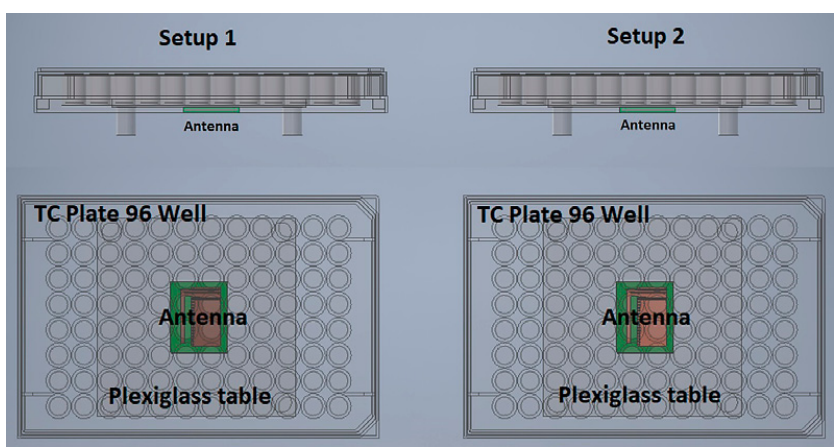

Figure 3. Experimental setup. Wireless digital transmission between 2 identical units was characterized by the physical parameters to achieve reliable results. The separate antenna was matched and tuned in order to achieve the maximum energy radiation in the Bluetooth frequency range, with a centre frequency of around $2.4 \mathrm{GHz}$. The S1.1 parameters for separate antenna are shown in Figure 4. For proper matching, lumped serial $(\mathrm{C} 1=0.43 \mathrm{pF})$ and parallel $(\mathrm{C} 2=1.58 \mathrm{pF})$ capacitors were needed. When approaching antenna to close to the plexiglass holder with the TC plate, the perfect matching and tuning were lost - energy transfer was far less that for single antenna. For simulation, the TC 96 well plate was characterized as a lossy material made from PS with density Rho $=, 000 \mathrm{~kg} / \mathrm{m}^{3}$ and epsilon constant 2.55 . For better results, the antenna should be placed at a minimum distance of $1.5 \mathrm{~mm}$ below the bottom side of the plexiglass sheet. The optimal but not perfect position is shown in Figure 5 . The simulation parameters were chosen in order to achieve a power introduced to the antenna of approximately $6 \mathrm{~mW}$. The electric and magnetic far fields distribution (reference $1 \mathrm{~m}$ away from antenna) is shown in Table 1. Far field power pattern is presented with cut angle 90, constant Phi angle and constant Theta angle. Isotropic polar graphs of far field E, H and power are collected in Table 2. The antenna with the examined cells were positioned in the zero position. The power distribution was asymmetric with main lob direction $132 \mathrm{deg}$ and maximum magnitude $0.000206 \mathrm{~W} / \mathrm{m}$. Fields distribution close to antenna in direct proximity to the examined cells were simulated $15 \mathrm{~mm}$ above the antenna. The electric field is more concentrated on one side of the TC plate, with a maximum magnitude of below $23 \mathrm{~V} / \mathrm{m}$ for continuous exposition.

For future experiments, a different shape of the antenna needs to be considered in order to achieve more homogeneous fields and power distribution over the sample. For a quasi- 
Table 1. Electric and magnetic far fields distribution

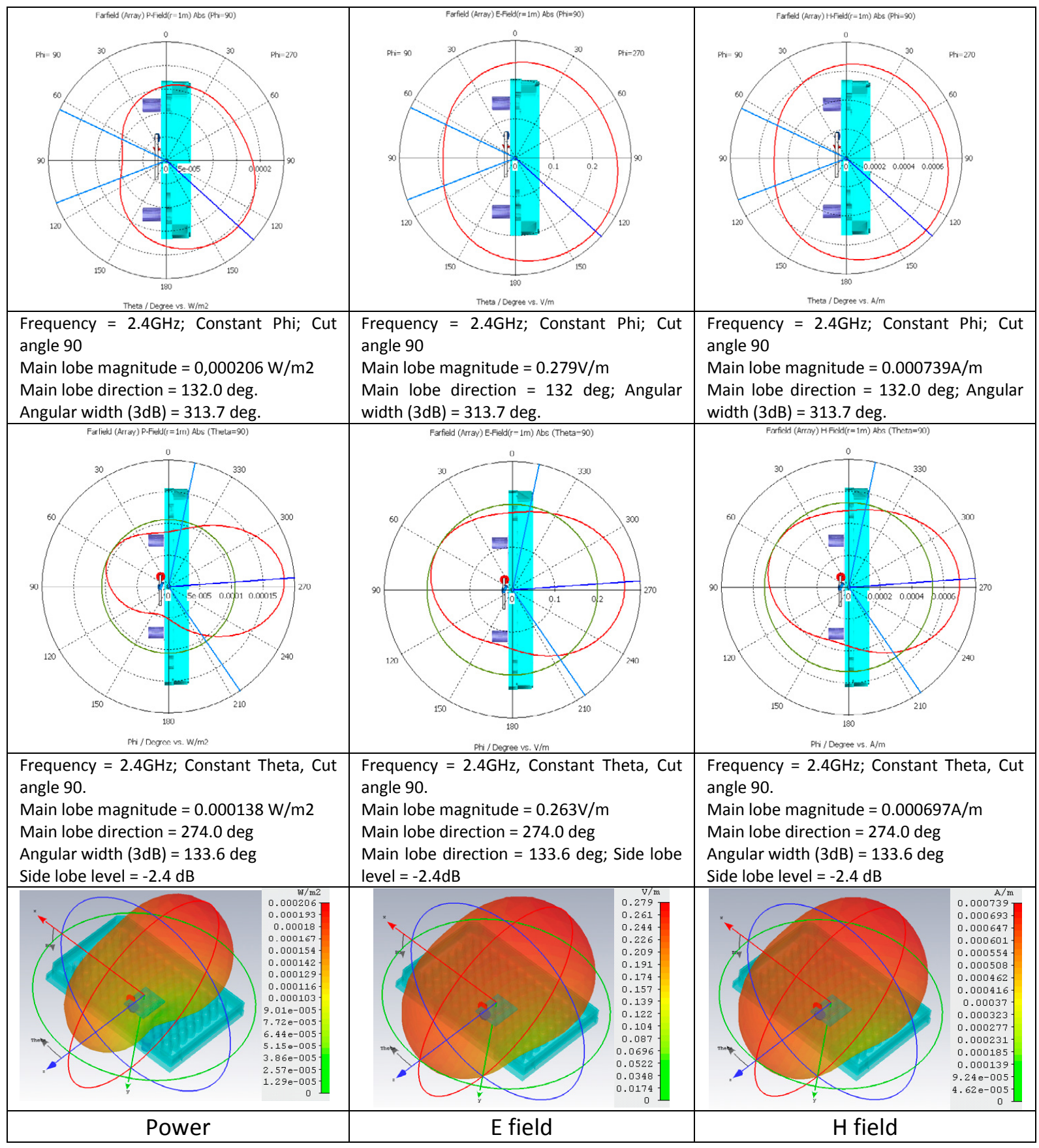

Table 2. Near antenna E, H fields and power distribution.

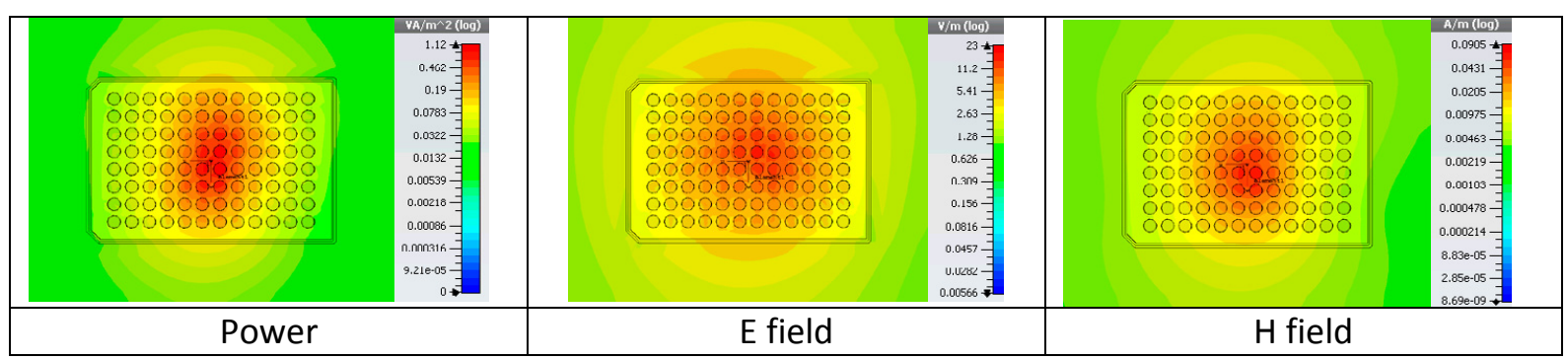




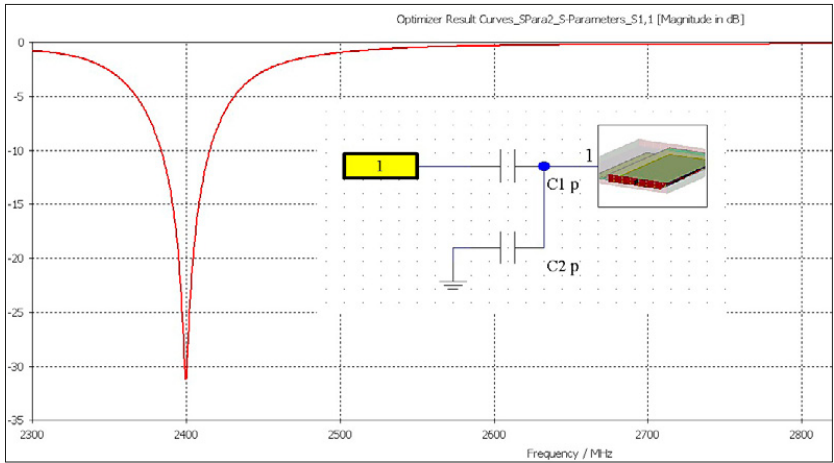

Figure 4. S1.1 parameters simulation results. Maximum electromagnetic radiation was achieved on frequency $2.4 \mathrm{GHz}$. Signal for wireless transmitting was introduced to port 1

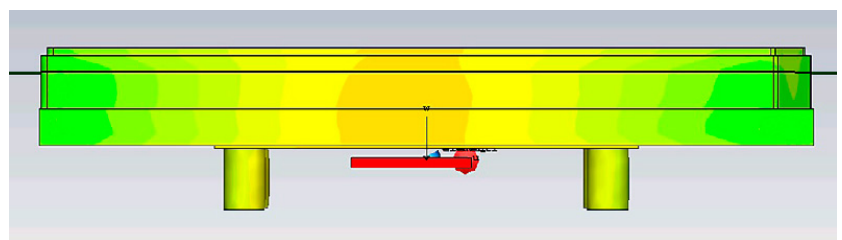

Figure 5. Optimal antenna position

continuous wave transmission over the Bluetooth, the average power could reach a maximum value of $50 \%$ of the power calculated in the simulation, which gives $0.56 \mathrm{~W} / \mathrm{m} 2,11.5 \mathrm{~V} / \mathrm{m}$ for the electric field and $0.045 \mathrm{~A} / \mathrm{m}$ for the magnetic field. The specific absorption rate is a measure of the rate at which RF energy is absorbed by the tissue, and in future it could be calculated either from the electric field or simulated.

Statistical analysis. The results were tested for normal distribution (Shapiro test) and homogeneity of variance (Bartlett test). For comparison between mean values, t-test was used. Values of $\mathrm{p}<0.05$ were considered as significant. All statistical analyses were performed using R version 3.4.1.

\section{RESULTS}

The influence of RF-EMF on individual cell types is presented in Figures 6-7. Cultivation of a particular cell type carried out under standard conditions without the use of an electromagnetic field served as a control. Measurements were conducted after 24, 48 and 72 hours. The viability of the control group was assumed to be $100 \%$ in each time. The viability of the studied groups was calculated as a percentage of the control (untreated) group viability in each respective time.

The electromagnetic field exposure caused a significant decrease in viability of the fibroblast after 24 and 48 hours of incubation, compared to the control group. After 72 hours viability, it decreased but the effects was not statistically significant.

In the case of the exposed prostate cancer cells, a significant decrease in viability was found after 24 hours of incubation and a significant increase after 48 and 72 hours, compared to the control samples.

Morphological analysis did not show any significant changes ineither cell line after exposure to RF-EMF and after the specified time of culture. The results concern both skin fibroblasts and the PC-3 line. Examples of morphologies

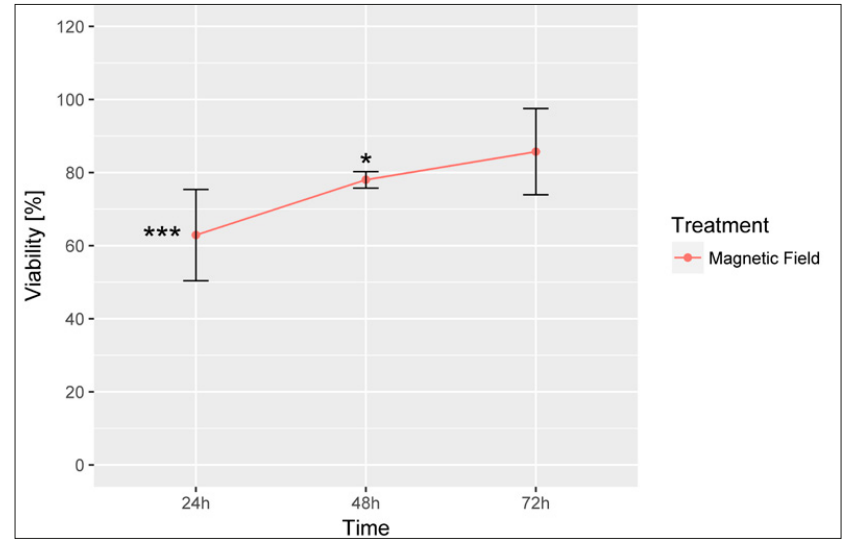

Figure 6. Changes in the viability of human fibroblasts cultivated in the magnetic field. Measurements were conducted after 24,48 and 72 hours. Viability of the control group was assumed to be $100 \%$ in each time. Viability of studied groups was calculated as a percentage of the control (untreated) group viability in a respective time.

* $p<0.05$ for the difference between viability of the control group and treated cells. *** $p<0.001$ for the difference between viability of the control group and treated cells.

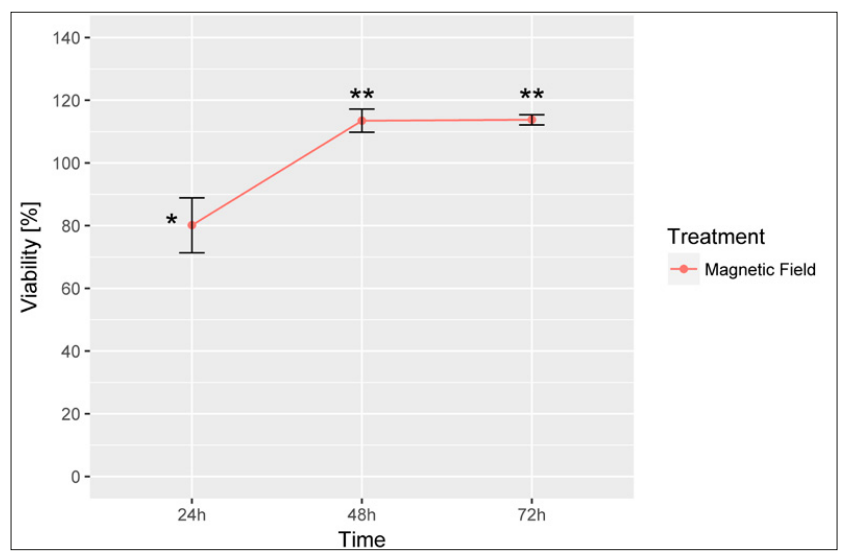

Figure 7. Changes in the viability of prostate cancer cells PC-3 cultivated in the magnetic field. Measurements were conducted after 24,48 and 72 hours. Viability of the control group was assumed to be $100 \%$ in each time. Viability of studied groups was calculated as a percentage of the control (untreated) group viability in a respective time.

* $\mathrm{p}<0.05$ for the difference between viability of the control group and treated cells. ** $p<0.01$ for the difference between viability of the control group and treated cells

of human fibroblasts after RF-EMF exposure and without exposure are shown in Figures 8-13.

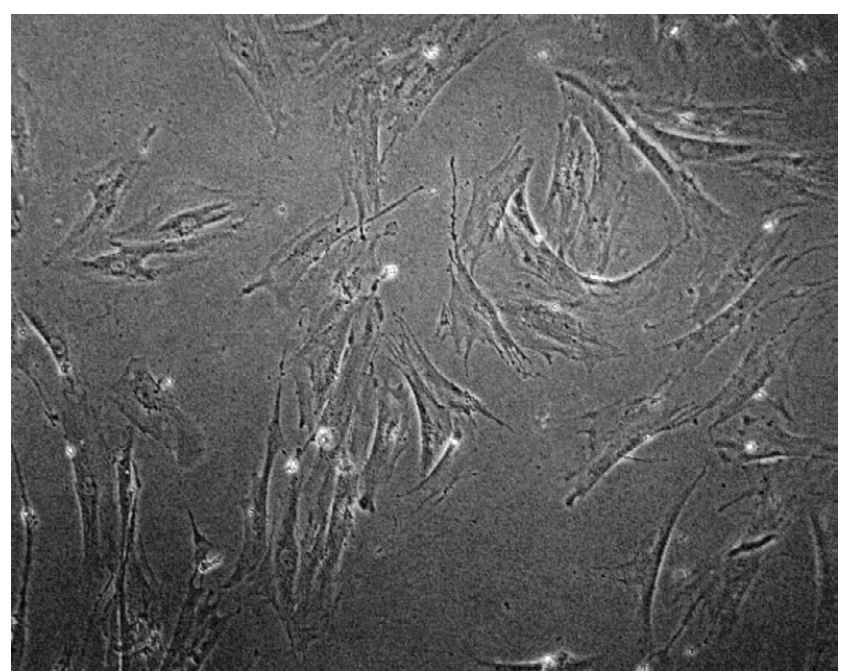

Figure 8. Human fibroblasts after $24 \mathrm{~h}$ cultivation in the electromagnetic field 


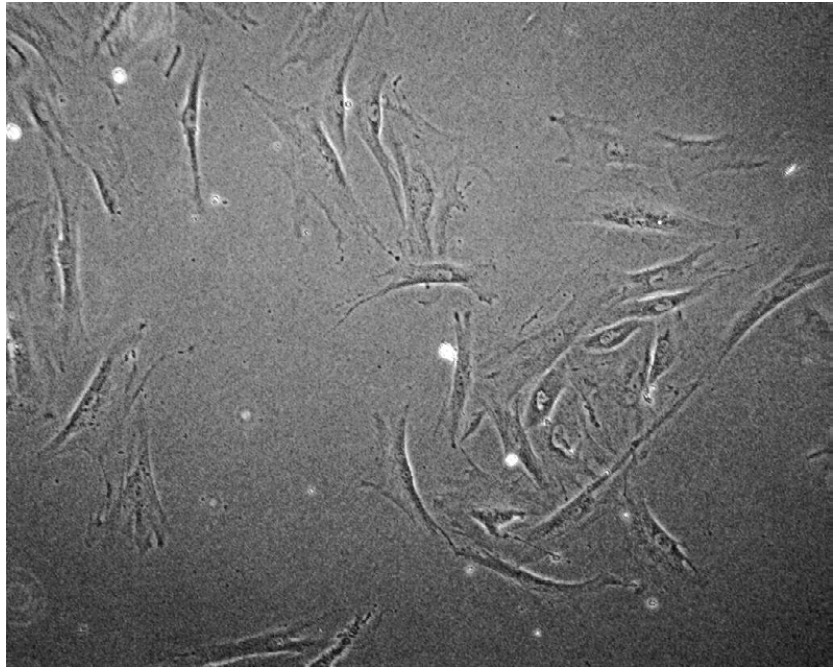

Figure 9. Human fibroblasts after $48 \mathrm{~h}$ cultivation in the electromagnetic field

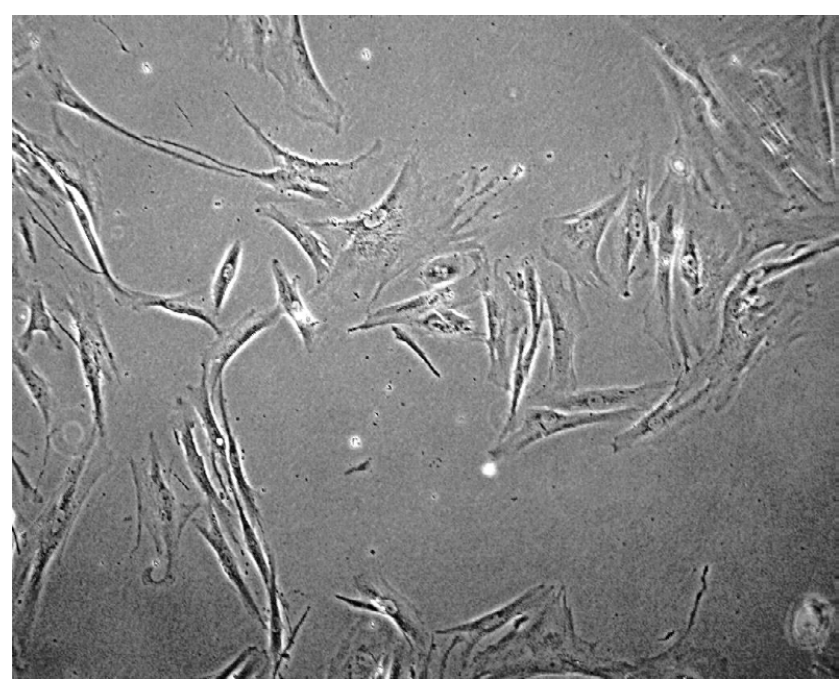

Figure 10. Human fibroblasts after $72 \mathrm{~h}$ cultivation in the electromagnetic field

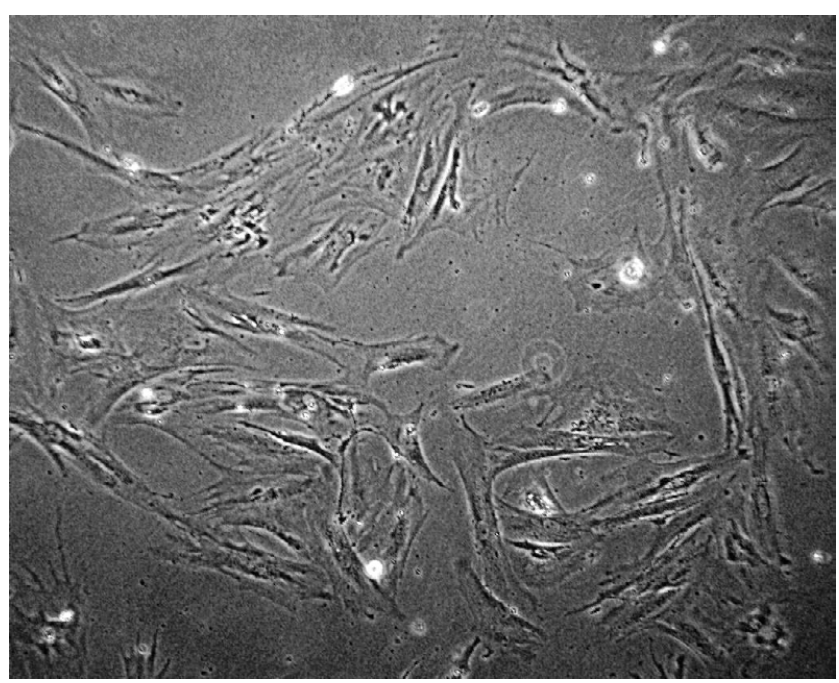

Figure 11. Human fibroblasts after $24 \mathrm{~h}$ breeding - control cells without magnetic field

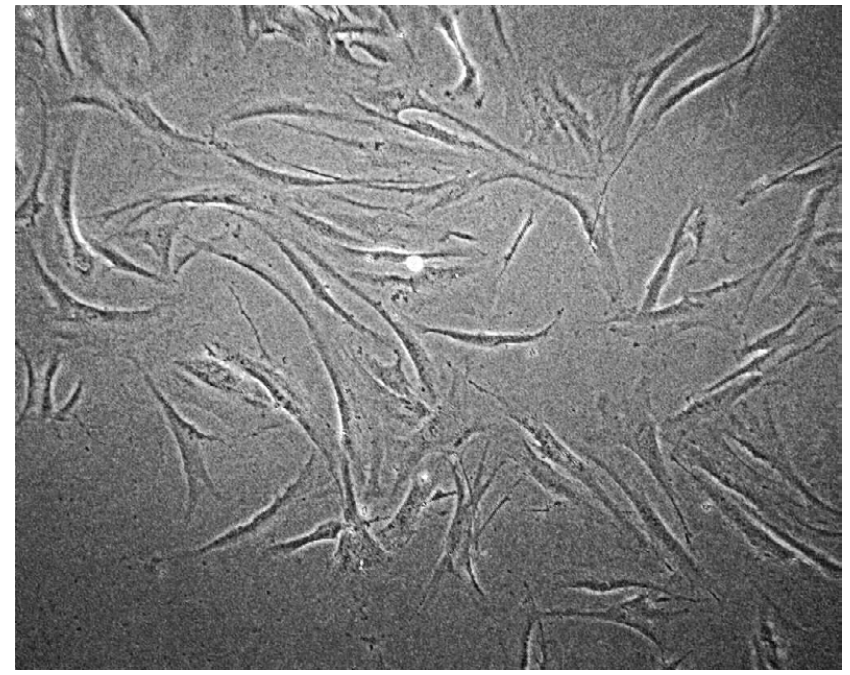

Figure 12. Human fibroblasts after $48 \mathrm{~h}$ breeding - control cells without magnetic field

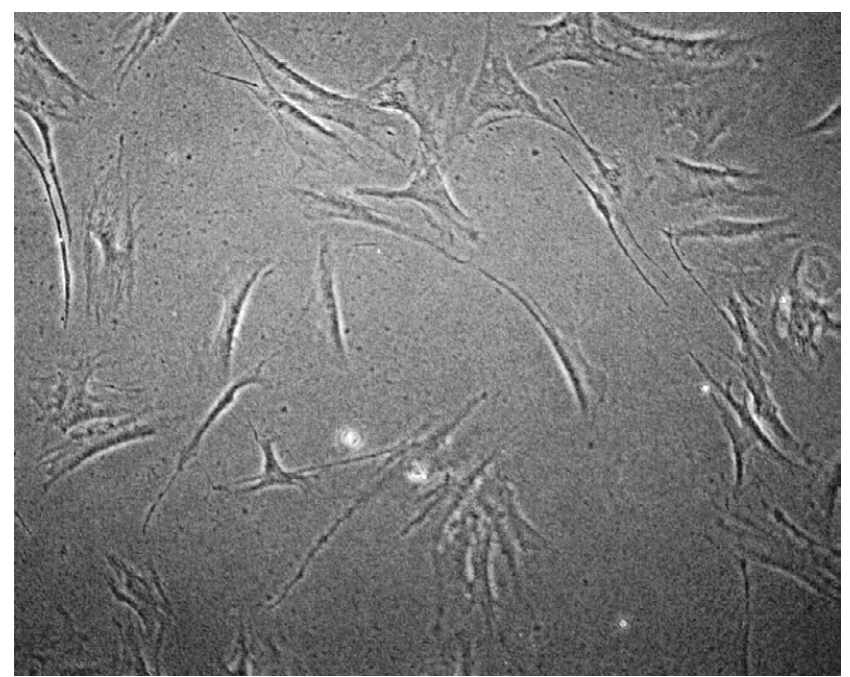

Figure 13. Human fibroblasts after $72 \mathrm{~h}$ breeding - control cells without magnetic field.

\section{DISCUSSION}

In the conducted research it was found that the RF electromagnetic field had a significant influence on cell metabolic activity. Exposure to the electromagnetic field caused a significant decrease in the viability of normal cells (fibroblasts) and a significant increase in cancer cells (PC-3 prostate cancer cell line).

Significant changes of proliferation in the normal cell were also observed by Kwee and Rasmark [40]. These authors found a decrease in the proliferation of human epithelial amnion cells exposed to $960 \mathrm{MHz}$ microwave fields. Capri et al. [41] also found a decrease in cell proliferation when human peripheral blood mononuclear cells were exposed in vitro to a $900 \mathrm{MHz}$ GSM (1 h/day for 3 days). Also in studies on animal cells, significant changes in proliferation were found after electromagnetic field exposure. Pavicic and Trosic [42] observed a decrease in the proliferation of Chinese hamster lung cells exposed to $864 \mathrm{MHz}$. Zhu et al. [43] showed that microwaves emitted by mobile phones lead to a significant reduction in the survival of in vitro cultured rat cortical neuronal cells. 
In other studies, the effecst of RF-EMF on other nongenotoxic functions of human cells were also observed. Some investigators have described an increased heat shock protein level in human epithelial and endothelial cells after RF-EMF exposure $[44,45]$. Analysis on whole genome cDNA arrays have shown alterations in gene expression after various RF exposure conditions (900 and 1,800 MHz) using different cell types (endothelial cells, lymphoblastoma cells, leukemia cells) [46]. Results obtained by Nylund and Leszczynski [47] also show that gene and protein expression were altered in exposed human endothelial cells, in response to one hour exposure of mobile phone radiation. In other studies, Dąbrowski et al. [48] determined the effect of RF- EMF on immune cell activity. Peripheral blood mononuclear cells exposed to $1,300 \mathrm{MHz}$ pulse-modulated RF fields showed that the electromagnetic field caused changes in immune cell activity.

Genotoxicity studies have also shown the negative effects of RF-EMF on cells. Diem et al. [49] observed DNA breakage in human diploid fibroblasts and in rat granulosa cell caused by mobile phone radiation $(1,800 \mathrm{MHz})$. Effects occurred after $16 \mathrm{~h}$ exposure. A short-term exposure (15 and $30 \mathrm{mi}$ ) to RFR $(900 \mathrm{MHz})$ from a mobile phone caused a significant increase in DNA single strand breaks in human hair root cells located around the ear which is used for the phone calls [50]. De Iuliis et al. [25] observed reactive oxygen species (ROS) production and DNA damage in human spermatozoa exposed in vitro to RFR at $1.8 \mathrm{GHz}$, and covering a range of SAR from $0.4 \mathrm{~W} / \mathrm{kg}-$ $27.5 \mathrm{~W} / \mathrm{kg}$. Campisi et al. [51] also found a significant increase in ROS levels and DNA fragmentation when they exposed human astrocytes to a modulated $900-\mathrm{MHz}$ electromagnetic field for 20 min. In other studies, Lai [52] showed DNA strand breaks in brain cells of rat exposed to $2,450-\mathrm{MHz}$ radiofrequency electromagnetic radiation. Garaj-Vrhovac et al. [53] found a correlation between the frequency of micronuclei and specific chromosome aberrations in human lymphocytes exposed in vitro to microwave radiation $\left(7.7 \mathrm{GHz}, 0.5,10,30 \mathrm{~mW} / \mathrm{cm}^{2}\right.$ for $10,30,60 \mathrm{~min})$. In all experimental conditions, the frequency of all types of chromosomal aberrations and the incidence of micronuclei were significantly higher than in the control samples. Cellular Micronucleus formation was also found by Koyama et al. [54], who exposed Chinese hamster ovary cells to a RF-EMF at 78 and $100 \mathrm{~W} / \mathrm{kg}$ for $18 \mathrm{~h}$.

In vitro studies have shown, similar to the presented research, that high frequency electromagnetic radiation not only causes changes in normal cells, but also in cancer cells. In a study carried out by Jin et al. [55] the human promyelocytic leukemia HL-60 cells were exposed to a continuous wave $900 \mathrm{MHz}$ RF-EMF for 1 h per day for 3 consecutive days, and showed a significant increase in viability and a decrease in apoptosis. In the current study, a significant decrease in viabilitywas found after the exposure of prostate cancer cells to radiofrequency electromagnetic field for 48 and 72 hours. Marinelli et al. [56] cultured acute T-lymphoblastoid leukemia cells in the presence of an unmodulated $900 \mathrm{MHz}$ EMF. It was shown that short exposure times (2_12 h), induced DNA breaks and early activation of both p53-dependent and independent apoptotic pathways. Longer continuous exposure (24-48 h) determined silencing of pro-apoptotic signals and activation of genes involved in both intracellular (Bcl-2) and extracellular (Ras and Akt1) pro-survival signaling. The authors have reported a better survival rate of T lymphoblastoid leukaemia cells exposed to $900 \mathrm{MHz}$. In other studies, Caraglia et al. [57] evaluated the in vivo effect of electromagnetic field at 1,950
$\mathrm{MHz}$ on human epidermoid cancer KB cells. The results of these tests indicate that EMF induces apoptosis through the inactivation of the ras $\rightarrow$ Erk survival signaling which is due to an enhanced degradation of ras and Raf-1 determined by a decreased expression of HSP90 and the consequent increase of proteasome dependent degradation. Ouadah et al. [58] studied the effects of radiofrequency electromagnetic fields (900 MHz, 5 days a week, $45 \mathrm{~min}$ a day) on in vivo brain tumours in Wistar rats. The results suggested that the action of RF-EMF causes a reduction of immune cell invasion and glioblastoma cell apoptosis.

\section{CONCLUSIONS}

The presented study shows that an RF electromagnetic field has a significant influence on cell metabolic activity. The results of the viability analysis of cells exposed to the electromagnetic field unambiguously indicate that normal human fibroblast cells decrease metabolic activity, while the survival of cancer cells (PC-3) increases in relation to an increase in RF-EMF incubation time.

On the basis of the obtained results, the hypothesis can be formulate that a high frequency electromagnetic field can have harmful effects on human cells.

In order to confirm the formulated hypothesis, it is recommended to continue the research on the influence of the RF electromagnetic field, including the genotoxic interactions on human cells.

\section{Funding information}

The publication was co-financed within the framework of a Ministry of Science and Higher Education program as 'Regional Initiative Excellence' in the years 2019-2022, Project No. 005/RID/2018/19.

\section{REFERENCES}

1. GSMA Mobile Economy. 2018. https://www.gsma.com/mobileeconomy/ wp-content/uploads/2018/05/The- Mobile-Economy-2018.pdf

2. World Health Organization (WHO). 2017. Electromagnetic fields and public health: mobile phones. http://www.who.int/mediacentre/ factsheets/fs193/en/. Accessed 17 Jan 2017.

3. Hardell L, Mild KH, Påhlson A, Hallquist A. Ionizing radiation, cellular telephones and the risk for brain tumours. Eur J Cancer Prev. 2001; 10: $523-529$.

4. Hardell L, Carlberg M, Mild KH. Case-control study on cellular and cordless telephones and the risk for acoustic neuroma or meningioma in patients diagnosed 2000-2003. Neuroepidemiol. 2005 a; 25(3): 120-128.

5. Hardell L, Sage C. Biological effect from electromagnetic field exposure and public exposure standards. Biomed Pharmacother 2008; 62(2): 104-109.

6. Hardell L, Carlberg M, Söderqvist F, Mild KH. Case-control study of the association between malignant brain tumours diagnosed between 2007 and 2009 and mobile and cordless phone use. Int J Oncol. 2013; 43(6): 1833-1845.

7. Prasad M, Kathuria P, Nair P, Kumar A, Prasad K. Mobile phone use and risk of brain tumours: a systematic review of association between study quality, source of funding, and research outcomes. Neurol Sci. 2017; 38(5): 797-810.

8. Cardis E, Deltour I, Mann S, Moissonnier M, Taki M, Varsier N, Wake $\mathrm{K}$, Wiart J. Distribution of RF energy emitted by mobile phones in anatomical structures of the brain. Phys Med Biol. 2008; 53: 2771-2783.

9. Hardell L, Carlberg M, Mild KH. Pooled analysis of two case-control studies on use of cellular and cordless telephones and the risk for malignant brain tumours diagnosed in 1997-2003. Int Arch Occup Environ Health. 2006; 79(8): 630-639.

10. Wiart J, Hadjem A, Wong MF, Bloch I. Analysis of RF exposure in the head tissues of children and adults. Phys Med Biol. 2008; 53(13): 3681-3695. 
11. Gandhi OP, Kang G. Some present problems and a proposed experimental phantom for SAR compliance testing of cellular telephones at 835 and $1900 \mathrm{MHz}$. Phys Med Biol. 2002; 47(9): 1501-1518.

12. Sadetzki S, Chetrit A, Jarus-Hakak A, Cardis E, Deutch Y, Duvdevani S, Zultan A, Novikov I, Freedman L,Wolf M. Cellular phone use and risk of benign and malignant parotid gland tumors-a nationwide case-control study. Am J Epidemiol. 2008; 167(4): 457-467.

13. Hardell L, Eriksson M, Carlberg M, Sundstro“m C, Mild KH. Use of cellular or cordless telephones and the risk for non-Hodgkin's lymphoma. Int Arch Occup Environ Health 2005 b; 8(8): 625-632.

14. Linet MS, Taggart T, Severson RK, Cerhan JR, Cozen W, Hartge P, Colt J. Cellular telephones and non-Hodgkin lymphoma. Int J Cancer 2006; 119(10): 2382-2388.

15. Hardell L, Carlberg M, Ohlson C-G, Westberg H, Eriksson M, Mild $\mathrm{KH}$. Use of cellular and cordless telephones and risk of testicular cancer. Int J Androl. 2007; 30(2): 115-122.

16. Lai H, Singh NP. Melatonin and a spin-trap compound block radiofrequency electromagnetic radiation-induced DNA strand breaks in rat brain cells. Bioelectromagnetics 1997; 18: 446-454.

17. Phillips JL, Singh NP, Lai H. Electromagnetic fields and DNA damage. Pathophysiology 2009; 16: 79-88.

18. Liu C, Duan W, Xu S, et al. Exposure to $1800 \mathrm{MHz}$ radiofrequency electromagnetic radiation induces oxidative DNA base damage in a mouse spermatocyte-derived cell line. Toxicol Lett. 2013; 218:2-9.

19. Kilgalton SJ, Simmons LW. Image content influences men's semen quality. Biol Lett. 2005; 1: 385-393.

20. Erogul O, Oztas E, Yildirim I, Kir T, Aydur E, Komesli G, Irkilata HC, IrmakMK, Peker AF. Effects of electromagnetic radiation from a cellular phone on human sperm motility:an vitro study. Arch Med Res. 2006; 7(7): 840-8433.

21. Davoudi M, Brössner C, Kuber W. Der Einfluss elektromagnetischer Wellen auf die Spermienmotilität. J Urol Urogynäkol. 2002; 9: 18-22.

22. Gutschi T, AI-Ali BM, Shamloul R, Pummer K, Trummer H. Impact of cell phone use on men's semen parameters. Andrologia 2011; 43(5): 312-316.

23. Wdowiak A, Wdowiak L, Wiktor H. Evaluation of the effect of using mobile phones on male fertility. Ann Agr Env Med. 2007; 14(1): 169-172.

24. Falzone N, Huyser C, Becker P, Leszezynski DR, Franken DR. The effect of pulsed $900 \mathrm{MHz}$ GSM mobile phone radiation on the acrosome reaction, head morphometry and zona binding of human spermatozoa. Int J Androl. 2011; 34(1): 20-26.

25. De Iullis GN, Newey RJ, King BV, Aitken RJ. Mobile phone radiation induces reactive oxygen species production and DNA damage in human spermatozoa in vitro. PLos One 2009; 4(7): e6446.

26. Avendano C, Mata A, Sanchez Sarmiento CA, Doncel GF. Use of laptop computers connected to internet through Wi-Fi decreases human sperm motility and increases sperm DNA fragmentation. Fertility Sterlity 2012; 97(1): 39-45.

27. Yan JG, Agresti M, Bruce T, Yan YH, Granlund A, Metaloub HS. Effects of cellular phone emissions on sperm motility in rats. Fertility Sterility 2007; 88(4): 957-64.

28. Otitoloju AA, Obe IA, Adewale OA, Otubanjo OA, Osunkalu VO. Preliminary study on the reduction of sperm head abnormalities in mice, Mus musculus exposed to radiofrequency radiations from global system for mobile communication base stations. Bull Environ Contamin Toxicol. 2010; 84(1): 51-54.

29. Salama N, Kishimoto T, Kanayama HO. Effects of exposure to a mobile phone on testicular function and structure in adult rabbit. Int J Androl. 2010; 33(1): 88-94.

30. Dasdag S, Akdag MZ, Ulukaya E, Uzunlar AK, Yegin D. Mobile phone exposure does not induce apoptosis on spermatogenesis in rats. Arch Med Res. 2008; 39(1): 40-44.

31. Aitken RJ, Bennetts LE, Sawyer D, Wiklendt AM, King BV. Impact of radiofrquency electromagnetic radiation on DNA integrity in the male germline. Int J Androl. 2005; 28(3): 171-179.

32. Gul A, Celebi H, Ugras S. The effects of microwaves emitted by cellular phones on ovarian follicles in rats. Arch Gynecol Obstet. 2009; 280(5) 729-33.

33. Nakamura H, Nagase H, Ogino K, Hatta K, Matsuzaki I. Uteroplacental circulatory disturbance mediated by prostaglandin $\mathrm{f} 2 \mathrm{alpha}$ in rats exposed to microwaves. Reprod Toxicol. 2000; 14(3): 235-240.

34. Koivisto M, Revonsuo A, Krause C, Haarala C, Sillanmäki L, Laine M, Hämäläinen H. Effects of $902 \mathrm{MHz}$ electromagnetic field emitted by cellular telephones on response times in humans. Neuroreport. 2000; 11(2): 413-415.

35. Krause CM, Sillanmaki L, Koivisto M, Haggqvist A, Saarela C, Revonsuo A, Laine M, Hamalainen H. Effects of electromagnetic fields emitted by cellular phones on the electroencephalogram during a visual working memory task. Int J Radiat Biol. 2000; 76(12): 1659-1667.

36. Hutter HP, Moshammer H, Wallner P, Kundi M. Subjective symptoms, sleeping problems and cognitive performance in subjects living near mobile phone base stations. Occup Env Med. 2006; 63(5): 307-313.
37. Huber R, Graf T, Cote KA, Wittmann L, Gallmann E, Matter D, Schuderer J, Kuster N, Borbely AA, Achermann P. Exposure to pulsed high-frequency electromagnetic field during waking affects human sleep EEG. Neuroreport. 2000; 11(15): 3321-3325.

38. Santini R, Santini P, Le Ruz P, Danze JM, Seigne M. Survey study of people living in the vicinity of cellular phone base stations. Electromag Biol Med. 2003; 22: 41-49.

39. Abdel-Rassoul G, El-Fateh OA, Salem MA, Michael A, Farahat F, ElBatanouny M, Salem E. Neurobehavioral effects among inhabitants around mobile phone base stations, Neurotoxicology 2007; 28: 434-440.

40. Kwee S, Raskmark P. Changes in cell proliferation due to environmental non-ionizing radiation: 2. Microwave radiation. Bioelectrochem Bioenerg. 1998; 44(2): 251-255.

41. Capri M, Scarcella E, Fumelli C. Bianchi E, Salvioli S, Mesirca P, Agostini C, Antolini A, Schiavoni A, Castellani G, Bersani F, Franceschi C. In vitro exposure of human lymphocytes to $900 \mathrm{MHz}$ CW and GSM modulated radiofrequency: studies of proliferation, apoptosis and mitochondrial membrane potential. Radiat Res. 2004; 162(2): 211-218.

42. Pavisic I, Trosic I. Influence of $864 \mathrm{MHz}$ electromagnetic field on growth kinetics of established cell line. Biologia 2008; 61(3): 321-325.

43. Zhu Y, Gao F, Yang X, Shen H, Liu W. The effect of microwave emission from mobile phones on neuron survival in rat central nervous system. Prog Electromagn Res. 2008; 82: 287-298.

44. Kwee S, Raskmark P, Velizarov S. Changes in cellular proteins due to environmental nonionizing radiation. 1. Heat shock proteins. Electroand Magnetobiol. 2001; 20(2): 141-152.

45. Leszczynski D, Joenväärä S, Reivinen J, Kuokka R. Non-thermal activation of the hsp27/p38MAPK stress pathway by mobile phone radiation in human endothelial cells: molecular mechanism for cancer and bloodbrain barrier-related effects. Differentiation 2002; 70(2-3): 120-129.

46. Remondini D, Nylund R, Reivinen J, Poulletier de Gannes F, Veyret B, Lagroye I, Haro E, Trillo MA, Capri M, Franceschi C, Schlatterer K, Gminski R, Fitzner R, Tauber R, Schuderer J, Kuster N, Leszczynski D, Bersani F, Maercker C. Gene expression changes in human cells after exposure to mobile phone microwaves. Proteomics 2006; 6(17): 4745-4754.

47. Nylund R, Leszczynsk D. Mobile phone radiation causes changes in gene and protein expression inhuman endothelial cell lines and the response seems to be genome- and proteome-dependent. Proteomics 2006; 6(17): 4769-4780

48. Dąbrowski MP, Stankiewicz W, Kubacki R, Sobiczewska E, S. Szmigielski S. Immunotropic effects in cultured humanblood mononuclear cells pre-exposedto low-level $1300 \mathrm{MHz}$ pulse-modulatedmicrowave field. Electromagn Biol Med. 2003; 22(1): 1-13.

49. Diem E, Schwarz C, Adlkofer F, Jahn O, Rudiger H. Non-thermal DNA breakage by mobile phone radiation $(1800 \mathrm{MHz})$ in human fibroblasts and in transformed GFSH-R17 rat granulosa cells in vitro. Mutat Res. 2005; 583(2): 178-183.

50. Çam ST, Seyhan N. Single -strand DNA breaks in human hair root cells exposed to mobile phone radiation. Int J Radiat Biol. 2012; 88(5): 420-424.

51. Campisi A, Gulino M, Acquaviva R, Bellia P, Raciti G, Grasso R, Musumeci F, Vanella A, Triglia A. Reactive oxygen species levels and DNA fragmentation on astrocytes in primary culture after acute exposure to low intensity microwave electromagnetic field. Neurosci Lett. 2010; 473(1): 52-55.

52. Lai H. Single-and double-strand DNA breaks in rat brain cells after acute exposure to radiofrequency electromagnetic radiation. Int J. Radiat Biol. 2009; 69(4): 513-521.

53. Garaj-Vrhovac V, Fučić A, Horvat D. The correlation between the frequency of micronuclei and specific chromosome aberrations in human lymphocytes exposed to microwave radiation in vitro. Mutation Res Lett. 1992; 281(3): 181-186.

54. Koyama S, Nakahara T, Wake K, Taki M, Isozumi Y, Miyakoshi J. Effects of high frequency electromagnetic fields on micronucleus formation in CHO-K1 cells. Mutation Res. 2003; 541(1-2): 81-89.

55. Jin Z, Zong C, Jiang B, Zhou Z, Tong J, Cao Y. The effect of combined exposure of $900 \mathrm{MHz}$ radiofrequency fields and doxorubicinin HL-60 cells. PLoS One 2012; 7: e46102.

56. Marinelli F, La Sala D, Cicciotti G, Cattini L, Trimarchi C, Putti S, Zamparelli A, Giuliani L, Tomassetti G, Cinti C. Exposure to $900 \mathrm{MHz}$ electromagnetic field induces an unbalance between pro-apoptotic and pro-survival signals in T-lymphoblastoid leukaemia CCRF-CEM cells. J Cell Physiol. 2004; 198(3): 324-332.

57. Caraglia M, Marra M, Mancinelli F, D’Ambrosio G, Massa R, Giordano A. Budillon A, Abbruzzese A, Bismuto E. Electromagnetic fields at mobile phone frequency induce apoptosis and inactivation of the multi-chaperone complex in human epidermoid cancer cells. J Cell Physiol. 2005; 204(2): 539-548.

58. Ouadah NS, Lecomte A, Robidel F, Olsson A, Deltour I, Schüz J,Kelly Blazy K,Villégier AS. Possible effects of radiofrequency electromagnetic fields on in vivo C6 brain tumors in Wistar rats. J Neuro-Oncol. 2018; 140(3): 539-546.

59. https://www.wbgroup.pl/produkt/fermio-em/ 